\title{
Analysis of starvation conditions that allow for prolonged culturability of Vibrio vulnificus at low temperature
}

\author{
Christine Paludan-Müller, Dieter Weichart, $\nmid$ Diane McDougald and \\ Staffan Kjelleberg
}

School of Microbiology and Immunology, University of New South Wales, Sydney 2052, Australia
Author for correspondence: Staffan Kjelleberg. Tel: +612 3852102. Fax: +6123136528.

e-mail: S.Kjelleberg@unsw.edu.au

\begin{abstract}
The response of the estuarine human pathogen Vibrio vulnificus to starvation for carbon, nitrogen or phosphorus, or all three nutrients simultaneously (multiple-nutrient), was examined with respect to the maintenance of culturability during incubation at low temperature. $V$. vulnificus showed similar survival patterns during starvation for the individual nutrients when kept at $24^{\circ} \mathrm{C}$. On the other hand, cultures prestarved at $24^{\circ} \mathrm{C}$ and then shifted to $5{ }^{\circ} \mathrm{C}$ maintained culturability at low temperature in a starvation-conditiondependent manner. Carbon and multiple-nutrient starvation were indistinguishable in their ability to mediate maintenance of culturability in the cold. Prolonged starvation for phosphorus had a similar effect, but nitrogen starvation did not allow for maintenance of culturability. Extracellular factors produced during starvation were not observed to have an effect on the culturability of cells incubated at low temperature. Protein synthesis during starvation for individual nutrients was analysed by two-dimensional PAGE of pulse-labelled proteins. Carbon and multiple-nutrient starvation gave nearly identical protein induction patterns involving at least 34 proteins, indicating that carbon starvation determines both responses. Nitrogen starvation for $1 \mathrm{~h}$ induced 24 proteins, while phosphorus starvation induced a set of 10 proteins after $1 \mathrm{~h}$ and about 40 proteins after $18 \mathrm{~h}$. It is suggested that starvation for carbon or phosphorus induces maintenance of culturability of $\boldsymbol{v}$. vulnificus incubated at low temperature via the synthesis of distinct sets of starvationspecific proteins.
\end{abstract}

Keywords: starvation, cold, cross-protection, Vibrio vulnificus, viable but nonculturable

\section{INTRODUCTION}

Vibrio vulnificus is a pathogenic, estuarine bacterium associated with primary septicaemia and severe wound infections. The numbers of this organism are especially high in oysters and other shellfish due to the filter-feeding activity of these animals. The development of viable but nonculturable (VBNC) cells (Colwell et al., 1985; Oliver, 1993) has been studied in great detail in this organism, which has been reported to lose the ability to form colonies at temperatures around $5{ }^{\circ} \mathrm{C}$ (Oliver et al., 1991; Wolf \& Oliver, 1992). The kinetics of the formation of

†Present address: Department of General and Marine Microbiology, Goteborg University, Medicinaregatan 9C, 41390 Goteborg, Sweden.

Abbreviation: VBNC, viable but nonculturable. nonculturable cells of $V$.vulnificus depends on the growth phase of the organism before temperature down-shift: cells which encounter stationary phase or starvation before exposure to low temperature exhibit a significant delay in the development of the VBNC state (Oliver et al., 1991; Weichart et al., 1992). It is feasible that the synthesis of starvation proteins may be involved in this prolonged maintenance of culturability displayed during low-temperature incubation.

To date, studies of the physiology of VBNC cells have been hampered by an almost complete shutdown of activity in these cells, which is reflected in the paucity of reports on the physiology of the VBNC state. In $V$. vulnificus, protein synthesis has been proposed to be shut down at $5{ }^{\circ} \mathrm{C}$ (Morton et al., 1992), rendering the direct analysis of molecular adaptation processes by approaches 
such as electrophoresis of pulse-labelled proteins and transposon mutagenesis ineffective for cells in this state. In order to obtain information on the formation of VBNC cells of $V$. vulnificus, we decided to study the maintenance of culturability as an indirect approach to elucidate this response.

The aim of the study described here was to obtain a more detailed understanding of the starvation-dependent maintenance of culturability in $V$. vulnificus at $5{ }^{\circ} \mathrm{C}$. The prolonged culturability of $V$. vulnificus during cold incubation after pre-starvation for carbon, nitrogen, phosphorus or multiple nutrients was examined, as was the significance of extracellular factors in the stationary phase. Through the use of two-dimensional PAGE, the induction of proteins in response to the different starvation conditions was analysed and correlated with the fate (culturability) of the cells during subsequent cold incubation. We propose that the investigation of the cellular processes involved in maintenance of culturability may allow for the identification of processes that regulate the formation of nonculturable cells, and may thus lead to an understanding of the VBNC state and its biological role.

\section{METHODS}

Bacterial strain and culture conditions. Vibrio vulnificus $\mathrm{C} 7184(\mathrm{~T})$ is a spontaneously derived isogenic and non-virulent mutant of the virulent and encapsulated environmental strain C7184(O) (Simpson et al., 1987). It exhibits the same response to cold incubation as the opaque variant (Wolf \& Oliver, 1992). $[(\mathrm{T})$ refers to a translucent and $(\mathrm{O})$ to an opaque colony morphology on agar plates which is related to capsule production.]

Cells of $\mathrm{C} 7184(\mathrm{~T})$ were routinely grown at $24^{\circ} \mathrm{C}$ on a rotary shaker in $2 \mathrm{M}$ medium, which is identical to the 'marine minimal medium' 3M (Östling et al., 1991), but modified to contain only $50 \%$ of the salts and is buffered with $40 \mathrm{mM}$ MOPS in analogy to the media used for culturing Escherichia coli (Neidhardt et al., 1974). It contains single defined inorganic nitrogen and phosphorus sources $\left(9 \cdot 25 \mathrm{mM} \mathrm{NH}_{4} \mathrm{Cl} ; 1.32 \mathrm{mM} \mathrm{K}_{2} \mathrm{HPO}_{4}\right)$, and $0 \cdot 2 \%(\mathrm{w} / \mathrm{v})$ glucose as a single carbon source. Starvation conditions were achieved by transferring washed growing cells to the medium lacking either carbon $(2 \mathrm{M}-\mathrm{C})$ or nitrogen $(2 \mathrm{M}-\mathrm{N})$ or phosphorus $(2 \mathrm{M}-\mathrm{P})$ or $\mathrm{C}, \mathrm{N}$ and $\mathrm{P}$ simultaneously (2M-CNP). The experiments were performed without shaking, at $24^{\circ} \mathrm{C}$ for starvation, and at $5{ }^{\circ} \mathrm{C}$ for cold incubation.

Determination of c.f.u. To assess the culturability of C7184(T) at $5{ }^{\circ} \mathrm{C}$, samples were taken at the indicated times and diluted in the respective starvation medium (see above). Drop plate counts (Hoben \& Somasegaran, 1982) were performed on VNSS-agar plates (Nyström et al., 1986) containing $50 \%$ of the reported amount of salts to equal the growth and starvation media. Plates were incubated for $24 \mathrm{~h}$ at $37^{\circ} \mathrm{C}$ before the assessment of c.f.u. Upon prolonged incubation for a total of $7 \mathrm{~d}$ no further colony development could be observed.

Pre-starvation and cold incubation experiments. Cells of $\mathrm{C} 7184(\mathrm{~T})$ were grown at $24^{\circ} \mathrm{C}$ overnight in $2 \mathrm{M}$ medium, transferred to fresh medium at a dilution of $1: 50$ and grown overnight; after repeating the dilution in fresh medium, the cells were grown to mid-exponential phase $\left(\mathrm{OD}_{610}=0 \cdot 15-0 \cdot 17\right.$; $1.8-3.7 \times 10^{8}$ c.f.u. $\mathrm{ml}^{-1}$ ). The culture was then split into $4 \times 25 \mathrm{ml}$ samples, each of which was harvested and washed twice $\left(12000 \mathrm{~g}, 15^{\circ} \mathrm{C}, 10 \mathrm{~min}\right.$, Sorvall RC5B plus centrifuge, SS34 rotor) in either $2 \mathrm{M}-\mathrm{N}, 2 \mathrm{M}-\mathrm{P}, 2 \mathrm{M}-\mathrm{C}$ or $2 \mathrm{M}-\mathrm{CNP}$, and the cells resuspended in 1 vol. of the respective starvation medium. Subsamples of these suspensions were starved for different periods at $24^{\circ} \mathrm{C}$ and then transferred to $5^{\circ} \mathrm{C}$. The starvation time was calculated from the start of the first wash. For comparison, exponentially growing cells were directly transferred to $5{ }^{\circ} \mathrm{C}$, or transferred after washing in either $2 \mathrm{M}-\mathrm{CNP}$ or $2 \mathrm{M}$ medium containing all nutrients $(2 \mathrm{M}+\mathrm{CNP})$. No difference in the kinetics of VBNC cell formation was observed between cells washed prior to cold incubation and those transferred directly to $5{ }^{\circ} \mathrm{C}$, or between cells resuspended in $2 \mathrm{M}-\mathrm{CNP}$ and $2 \mathrm{M}+\mathrm{CNP}$. The initial colony counts prior to cold incubation were between $1.7 \times 10^{6}$ c.f.u. $\mathrm{ml}^{-1}$ and $3.5 \times 10^{6}$ c.f.u. $\mathrm{ml}^{-1}$ in low-density experiments (suspensions diluted 1:100 in the respective starvation media), and between $1 \cdot 2 \times 10^{8}$ c.f.u. $\mathrm{ml}^{-1}$ and $4.9 \times 10^{8}$ c.f.u. $\mathrm{ml}^{-1}$ in high-density experiments (undiluted suspensions).

Treatment of cells prior to cold incubation. In order to test for the possibility that extracellular factors regulate or modulate the fate of starved cells during cold incubation, cell-free supernatants from a variety of sources were added in a ratio of $1: 1$ to cell suspensions and their culturability compared to suspensions which had been diluted 1:1 with fresh starvation medium $(2 \mathrm{M}-\mathrm{CNP})$. Supernatants were obtained from populations of $V$. vulnificus $\mathrm{C} 7184(\mathrm{~T})$ which had been starved in $2 \mathrm{M}-\mathrm{CNP}$ for 2 or $6 \mathrm{~d}$ at $24^{\circ} \mathrm{C}$, and from stationary-phase cultures of the following organisms grown for $2 \mathrm{~d}$ at $24^{\circ} \mathrm{C}$ in Luria broth containing $15 \mathrm{~g} \mathrm{NaCl}^{-1}: V$. vulnificus $\mathrm{C} 7184(\mathrm{~T}), V$. vulnificus $\mathrm{C} 7184(\mathrm{O}), V$. fischeri, $V$. harveyi and Vibrio sp. S14. The cultures were centrifuged at $12000 \mathrm{~g}$ (SS34, Sorvall RC5B plus) for $30 \mathrm{~min}$ at $15^{\circ} \mathrm{C}$ and sterile-filtered twice using $0.2 \mu \mathrm{m}$ pore size MFS cellulose acetate filters to obtain sterile supernatants.

Cells of C7184(T) grown to mid-exponential phase were also amended with the protease inhibitor $\alpha$-2-macroglobulin (from bovine plasma, Boehringer Mannheim) to test whether extracellular proteases are involved in the maintenance of culturability. The chemical was freshly dissolved in $2 \mathrm{M}-\mathrm{CNP}$, sterilefiltered using MFS $0.2 \mu \mathrm{m}$ pore size cellulose acetate filters, and added to the cells at the time of resuspension in the final medium. The action of $\alpha$-2-macroglobulin was tested by the addition of the protease substrate hide powder azure (HPA) to triplicate cultures of $V$. vulnificus $\mathrm{C} 7184(\mathrm{~T})$ starved in $2 \mathrm{M}-\mathrm{CNP}$ at $24^{\circ} \mathrm{C}$. A final concentration of $50 \mu \mathrm{g}$ protease inhibitor $\mathrm{ml}^{-1}$ efficiently suppressed any protease activity of the organism at $24^{\circ} \mathrm{C}$ : no breakdown of HPA could be observed for at least $5 \mathrm{~d}$ in the samples treated with $\alpha$-2-macroglobulin, whereas untreated controls displayed significant activity of protease, as judged by breakdown of HPA, after $2 \mathrm{~d}$ at $24^{\circ} \mathrm{C}$.

Pulse labelling of $\mathrm{C7184}(\mathrm{T})$ for two-dimensional PAGE. Cells of $\mathrm{C} 7184(\mathrm{~T})$ were grown in $2 \mathrm{M}$ medium at $24^{\circ} \mathrm{C}$ and labelled during exponential growth (mid-exponential phase), after $1 \mathrm{~h}$ of carbon, nitrogen or multiple (CNP) starvation, and after 1, 18, 21 or $24 \mathrm{~h}$ of phosphorus starvation at $24^{\circ} \mathrm{C}$. Labelling was performed at $24^{\circ} \mathrm{C}$ by incubating $0.5 \mathrm{ml}$ of the cultures with $64 \mu \mathrm{Ci}(2.38 \mathrm{MBq}){ }^{35} \mathrm{~S}$ ]methionine [sp. act. $1000 \mathrm{Ci} \mathrm{mmol}^{-1}$ $\left(37 \mathrm{TBq} \mathrm{mmol}^{-1}\right)$ ]. The incorporation was allowed to proceed for $10 \mathrm{~min}$ during exponential growth, for $15 \mathrm{~min}$ after starvation for $1 \mathrm{~h}$, and for $60 \mathrm{~min}$ after starvation for 18,21 or $24 \mathrm{~h}$. Incorporation was stopped by chasing with $50 \mathrm{mM}$ unlabelled methionine for $4 \mathrm{~min}$. The cell suspensions were centrifuged $\left(4^{\circ} \mathrm{C}, 20 \mathrm{~min}, 20000 \mathrm{~g}\right.$, Heraeus Sepatech Biofuge 17RS, rotor 1379) and the pellets frozen at $-70^{\circ} \mathrm{C}$.

The bacterial pellets were lysed with $0.3 \%(\mathrm{w} / \mathrm{v})$ SDS, $200 \mathrm{mM}$ $\beta$-mercaptoethanol, $28 \mathrm{mM}$ Tris $/ \mathrm{HCl}$ and $22 \mathrm{mM}$ Tris base by 
incubation at $100^{\circ} \mathrm{C}$ for $2 \mathrm{~min}$, followed by $5 \mathrm{~min}$ at $24^{\circ} \mathrm{C}$, and subsequently placed on ice. DNase $\left(1 \mathrm{mg} \mathrm{ml}^{-1}\right)$ and RNase $\left(0.25 \mathrm{mg} \mathrm{ml}^{-1}\right)$, in a buffer consisting of $24 \mathrm{mM}$ Tris base, $476 \mathrm{mM}$ Tris $/ \mathrm{HCl}$ and $50 \mathrm{mM} \mathrm{MgCl}$, were added and the suspensions incubated on ice for $20 \mathrm{~min}$. Pre-heated $\left(37^{\circ} \mathrm{C}\right)$ lysis buffer $[9.9 \mathrm{M}$ urea, $4 \%(\mathrm{v} / \mathrm{v})$ Nonidet P-40, $2.2 \%(\mathrm{v} / \mathrm{v})$ Ampholytes (Millipore $\mathrm{pH} 4-8$ ), $5 \%(\mathrm{v} / \mathrm{v}) \boldsymbol{\beta}$-mercaptoethanol] was added to extract the precipitated protein. To prevent contamination of the protein samples, cell debris was removed by centrifugation for $20 \mathrm{~min}\left(20000 \mathrm{~g}, 4^{\circ} \mathrm{C}\right.$, centrifuge and rotor as above) before loading the samples onto the first dimension.

Resolution of pulse-labelled cell proteins on two-dimensional polyacrylamide gels. Two-dimensional PAGE was performed by the method of O'Farrell (1975) with modifications. The first dimension was an isoelectric focusing gel containing $4.1 \%(\mathrm{w} / \mathrm{v})$ polyacrylamide and $6.25 \%(\mathrm{v} / \mathrm{v})$ ampholytes ( $\mathrm{pH} 4-8$, Millipore), and the second dimension was a $11.5 \%(\mathrm{w} / \mathrm{v})$ polyacrylamide gel. Equivalent amounts of radioactivity ( $10^{6}$ d.p.m.) were loaded for each set of gels. Autoradiograms were prepared by exposure to Fuji RX film for $8 \mathrm{~d}$ to permit visualization of the ${ }^{35} \mathrm{~S}$-labelled proteins. All settings and conditions were according to Millipore specifications. Pulse labelling and electrophoretic analysis of proteins were carried out at least in duplicate from separate experiments, and data reported are representative of these experiments.

\section{RESULTS}

\section{Starvation survival of $V$. vulnificus $\mathrm{C7184}(\mathrm{T})$}

Exponentially growing cells were washed and resuspended in defined starvation media which lacked either one essential nutrient $(\mathrm{N}, \mathrm{P}$ or $\mathrm{C})$ or all three at the same time (multiple starvation, $-\mathrm{CNP}$ ), and held at $24^{\circ} \mathrm{C}$ without shaking. Culturability was maintained at similar levels for up to $45 \mathrm{~d}$ at $24^{\circ} \mathrm{C}$ under all starvation conditions tested (Table 1). In order to verify that the cells were growth-limited by the respective nutrient, the lacking nutrient was added back to a subsample of the experiment after $1 \mathrm{~d}$ of starvation, and the cultures kept at $24^{\circ} \mathrm{C}$ with shaking. After an additional $24 \mathrm{~h}$ incubation, the amended samples showed an increase in c.f.u. of 35.5 ,

\section{Table 1. Survival of $V$. vulnificus $\mathrm{C7184(T)}$ at $24^{\circ} \mathrm{C}$} during starvation

The initial culturable cell count was between $2.19 \times 10^{6}$ and $3.5 \times 10^{6}$ c.f.u. $\mathrm{ml}^{-1}$, and the data shown are means, with sD in parentheses, of four independent experiments in the case of cells starved of carbon and multiple nutrients, and of seven independent experiments in the case of cells starved of phosphorus and nitrogen.

\begin{tabular}{|lrrrr|}
\hline \multirow{2}{*}{$\begin{array}{l}\text { Time } \\
\text { (d) }\end{array}$} & \multicolumn{4}{c|}{ Survival (\% of initial c.f.u.) } \\
\cline { 2 - 5 } & Carbon & Phosphorus & Nitrogen & Multiple* \\
\hline 10 & $18 \cdot 4(4 \cdot 3)$ & $44 \cdot 0(13 \cdot 0)$ & $23.9(16 \cdot 1)$ & $17 \cdot 2(5 \cdot 4)$ \\
20 & $7 \cdot 8(2 \cdot 1)$ & $18 \cdot 8(7 \cdot 1)$ & $5.33(2.5)$ & $10 \cdot 5(3 \cdot 2)$ \\
45 & $3.9(3 \cdot 7)$ & $6.5(4 \cdot 4)$ & $4.0(2 \cdot 8)$ & $4 \cdot 0(1 \cdot 8)$ \\
\hline
\end{tabular}

* Starvation for carbon, nitrogen and phosphorus simultaneously.

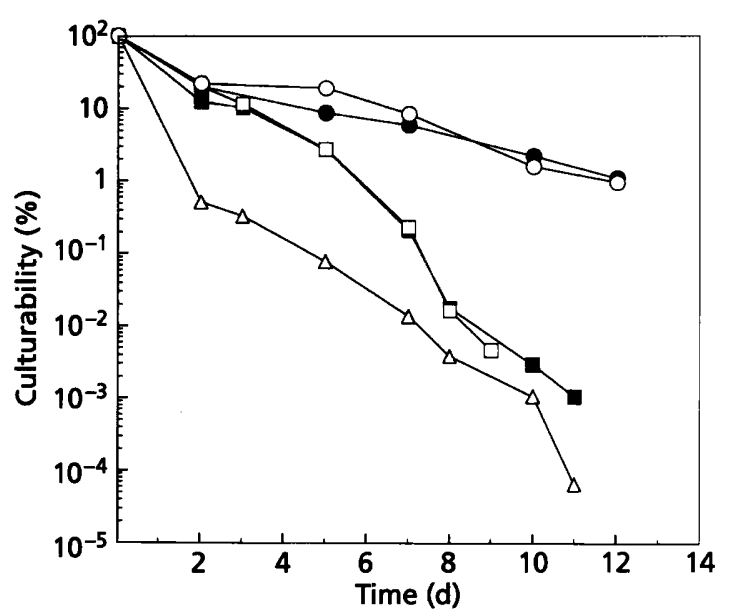

Fig. 1. Culturability of $V$. vulnificus at $5^{\circ} \mathrm{C}$ after pre-starvation for carbon or after multiple starvation for carbon, nitrogen and phosphorus (CNP). Exponential-phase cells were diluted in $2 \mathrm{M}-\mathrm{CNP}$ and immediately shifted to $5^{\circ} \mathrm{C}(\triangle)$, or were prestarved at $24^{\circ} \mathrm{C}$ for carbon $(\square, O)$ or $\operatorname{CNP}(\square, 0)$ for $1 \mathrm{~h}(\square, \square)$ or $24 \mathrm{~h}(0,0)$ prior to shifting to $5^{\circ} \mathrm{C}$. Data are presented as percentages of the initial count $\left(1.7 \times 10^{6}\right.$ c.f.u. $\left.\mathrm{ml}^{-1}\right)$ and are representative of three independent experiments.

$30 \cdot 1$ and $40 \cdot 8$ times the initial count for the carbon-, nitrogen- and phosphorus-starved cultures, respectively. The unamended samples, on the other hand, showed a slight decrease in c.f.u., providing evidence that the starving cultures were growth-limited for the lacking substrate. In the case of cells starved for multiple nutrients, only the simultaneous addition of all three nutrients $(\mathrm{C}, \mathrm{P}$ and $\mathrm{N})$ led to growth; no single nutrient $(\mathrm{C}, \mathrm{P}$ or $\mathrm{N})$, and no combination of two of the three nutrients, led to an increase in c.f.u. after $24 \mathrm{~h}$ at $24^{\circ} \mathrm{C}$. This control experiment proves that multiple-nutrientstarved cells are limited for all three nutrients.

\section{Effect of pre-starvation on culturability at $5^{\circ} \mathrm{C}$}

To determine which type of pre-starvation allows for maintenance of culturability during low-temperature incubation in $V$. vulnificus $\mathrm{C} 7184(\mathrm{~T})$, the cells were starved for the individual nutrients carbon, nitrogen or phosphorus (C, N or $\mathrm{P}$ ) or for all three simultaneously (multiple starvation, - CNP), and culturability was assessed during subsequent incubation at $5{ }^{\circ} \mathrm{C}$. For comparison, non-starved exponentially growing cells were transferred to $5{ }^{\circ} \mathrm{C}$ and their culturability determined.

Exponentially growing cells that had been transferred to $5^{\circ} \mathrm{C}$ without prior starvation displayed a rapid decline in c.f.u. during the first $2 \mathrm{~d}$ to less than $1 \%$ of the initial colony count of $1.7 \times 10^{6}$ c.f.u. $\mathrm{ml}^{-1}$. After $11 \mathrm{~d}$, less than $0.0001 \%$ culturable cells could be detected (Fig. 1). One hour of pre-starvation for carbon (C) or multiple nutrients (CNP) at $24^{\circ} \mathrm{C}$ resulted in prolonged culturability at $5{ }^{\circ} \mathrm{C}$. After $3 \mathrm{~d}$, cell numbers equivalent to approximately $10 \%$ of the initial colony counts were still culturable, compared to $0 \cdot 12 \%$ of the non-starved cells (Fig. 1). After $8 \mathrm{~d}$ cold 


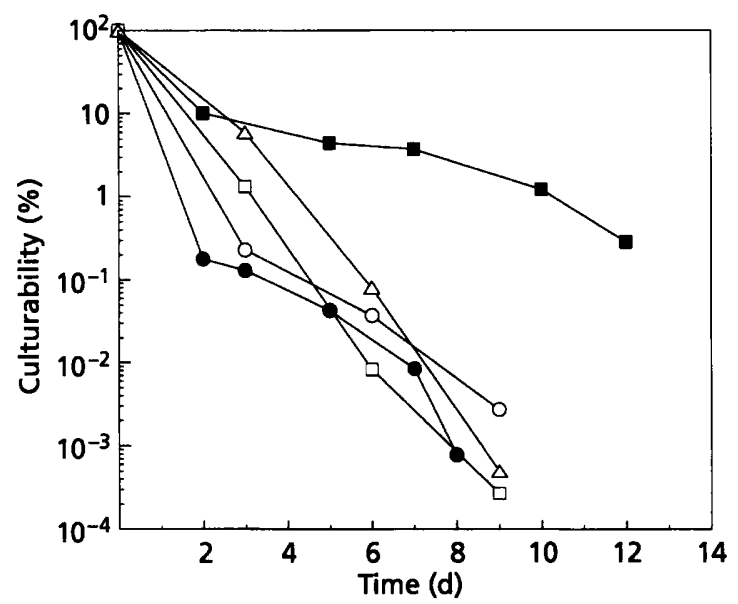

Fig. 2. Culturability of $V$. vulnificus at $5{ }^{\circ} \mathrm{C}$ after pre-starvation for nitrogen and phosphorus. Cultures were pre-starved for nitrogen at $24^{\circ} \mathrm{C}$ for $1 \mathrm{~h}(0), 24 \mathrm{~h}(\square)$ or $72 \mathrm{~h}(\Delta)$, or prestarved for phosphorus at $24^{\circ} \mathrm{C}$ for $1 \mathrm{~h}(\mathrm{O})$ or $24 \mathrm{~h}(\square)$, prior to shifting to $5^{\circ} \mathrm{C}$. Data are presented as percentages of the initial count $\left(2.5 \times 10^{6}\right.$ c.f.u. $\left.\mathrm{ml}^{-1}\right)$ and are representative of three independent experiments.

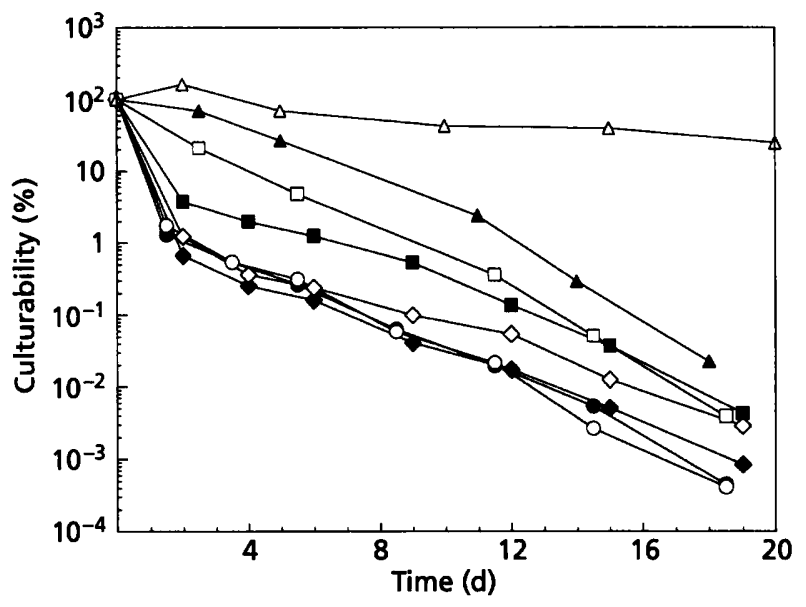

Fig. 3. Culturability of $V$. vulnificus at $5^{\circ} \mathrm{C}$ after pre-starvation for phosphorus for $3-40 \mathrm{~h}$. Cultures were pre-starved for phosphorus at $24^{\circ} \mathrm{C}$ for $3 \mathrm{~h}(0), 6 \mathrm{~h}(0), 12 \mathrm{~h}(\diamond), 15 \mathrm{~h}(\diamond)$, $18 \mathrm{~h}(\square), 24 \mathrm{~h}(\square)$ and $40 \mathrm{~h}(\Delta)$, prior to incubation at $5^{\circ} \mathrm{C}$. For comparison, the data from a parallel sample kept at $24^{\circ} \mathrm{C}$ throughout the experiment is shown $(\Delta)$. Data are presented as percentages of the initial count $\left(2.2 \times 10^{8}\right.$ c.f.u. $\left.\mathrm{ml}^{-1}\right)$ and are representative of three independent experiments.

incubation, the culturability of cells pre-starved for $1 \mathrm{~h}$ closely resembled that of non-starved cells (Fig. 1). Of cells that had been starved for carbon or multiple nutrients at $24{ }^{\circ} \mathrm{C}$ for $24 \mathrm{~h}$ prior to cold incubation, roughly $7 \%$ remained culturable after $7 \mathrm{~d}$, and $1 \%$ after $12 \mathrm{~d}$ (Fig. 1).

Pre-starvation for nitrogen for 1 or $24 \mathrm{~h}$ at $24{ }^{\circ} \mathrm{C}$ resulted in a decline in culturability to $0.25 \%$ or $1.5 \%$ culturable cells after $3 \mathrm{~d}$ cold incubation, respectively, and to less than $0.01 \%$ after $9 \mathrm{~d}$ (Fig. 2). Increasing the time of prestarvation for nitrogen at $24^{\circ} \mathrm{C}$ to $72 \mathrm{~h}$ did not allow for maintenance of culturability (Fig. 2). Thus, cells starved for nitrogen prior to cold incubation displayed a loss of culturability similar to that of non-starved cells irrespective of the duration of starvation.

Pre-starvation for phosphorus for $1 \mathrm{~h}$ resulted in a decline in culturability at $5{ }^{\circ} \mathrm{C}$ indistinguishable from the situation in the absence of starvation: $0.1 \%$ remained culturable after $2 \mathrm{~d}$ of cold incubation, and $0.001 \%$ after $8 \mathrm{~d}$ (Fig. 2). Starvation for phosphorus for up to $15 \mathrm{~h} \mathrm{had}$ a negligible effect, while pre-starvation for $18 \mathrm{~h}$ led to significantly prolonged culturability at low temperature (Fig. 3). Longer periods of pre-starvation led to further delay in the loss of culturability: when the culture was pre-starved for $24 \mathrm{~h}$, approximately $20 \%$ and $1 \%$ of the initial c.f.u. $\mathrm{ml}^{-1}$ was retained after $2 \mathrm{~d}$ and $10 \mathrm{~d}$ at $5{ }^{\circ} \mathrm{C}$, respectively (Figs 2 and 3). In all cases starved cells maintained at $24^{\circ} \mathrm{C}$ remained culturable throughout the experiment (Table 1, Fig. 3).

The cold incubation experiments were performed at low and high cell densities: the cultures were subjected to starvation and cold incubation either undiluted or diluted 1:100 in the respective starvation medium, with final densities of roughly $2 \times 10^{8}$ c.f.u. $\mathrm{ml}^{-1}$ and $2 \times 10^{6}$ c.f.u. $\mathrm{ml}^{-1}$, respectively (see Methods). No difference in the kinetics of the loss of culturability between the experiments with different cell densities was observed for carbon, nitrogen, or multiple (CNP) starvation. In contrast, prolonged phosphorus starvation at high cell density induced an enhanced rate of VBNC cell formation at $5^{\circ} \mathrm{C}$ relative to phosphorus starvation at low cell densities. In other words, the starvation-induced alteration in the kinetics of VBNC cell formation appears at later times at high cell densities. For this reason, in the case of phosphorus starvation, data from experiments with low (Fig. 2) and high cell densities (Fig. 3) are presented. The data from high-density experiments were used as the basis for the interpretation of the twodimensional electrophoretic analysis of proteins induced by phosphorus starvation.

\section{Effect of extracellular products on culturability at $5^{\circ} \mathrm{C}$}

The addition of supernatants of suspensions of $V$. vulnificus $\mathrm{C} 7184(\mathrm{~T})$ starved in $2 \mathrm{M}-\mathrm{CNP}$ (for 2 or $6 \mathrm{~d}$ at $24^{\circ} \mathrm{C}$ ), or supernatants of stationary-phase cultures of $V$. vulnificus $\mathrm{C} 7184(\mathrm{~T}), V$. vulnificus $\mathrm{C} 7184(\mathrm{O}), V$. fischeri, $V$. barveyi or Vibrio sp. S14 immediately prior to cold incubation showed no effect on culturability (data not shown).

The effect of inhibition of extracellular proteases was tested in order to account for the possibility that proteases induced during starvation might mediate the maintenance of culturability at $5{ }^{\circ} \mathrm{C}$ by degrading proteinaceous factors in the supernatants. Cells which had not been pre-starved retained $0.007 \%$ (mean of four replicates, SD, $0.05 \%$ ) of the initial c.f.u. $\left(3.46 \times 10^{6} \mathrm{ml}^{-1}\right)$ after incubation at $5{ }^{\circ} \mathrm{C}$ for $9 \mathrm{~d}$. After the same time of cold incubation, cells prestarved at $24^{\circ} \mathrm{C}$ for $22 \mathrm{~h}$ in the presence of $50 \mu \mathrm{g} \mathrm{ml}^{-1}$ of the non-specific protease inhibitor $\alpha$-2-macroglobulin displayed maintenance of $10 \%(n=4, \mathrm{SD}=4 \cdot 3 \%)$ of the 
initial count, and untreated control cells starved for $22 \mathrm{~h}$ maintained $30 \%(n=4, \mathrm{sD}=17 \cdot 3 \%)$ of the initial count. These results indicate that the inhibition of protease activity during starvation does not affect the maintenance of culturability of cells incubated at $5{ }^{\circ} \mathrm{C}$.

\section{Two-dimensional gel analysis of proteins induced after $1 \mathrm{~h}$ of carbon, nitrogen, phosphorus or multiple-nutrient starvation}

Proteins expressed by cells subjected to carbon, phosphorus, nitrogen or multiple-nutrient starvation were detected by pulse-labelling and subsequent two-dimensional gel electrophoresis. To be able to compare the protein induction patterns from cells exposed to different starvation conditions, cells were pulse-labelled at the same time of starvation for all the conditions studied. Based on the results described above, the labelling of proteins with $\left.{ }^{35} \mathrm{~S}\right]$ methionine was carried out after $1 \mathrm{~h}$ of starvation at $24{ }^{\circ} \mathrm{C}$ since at this time both carbon and multiple starvation exhibited a significant effect on the culturability of the cells during subsequent cold incubation. In addition, cells were also pulse-labelled at 18, 21 and $24 \mathrm{~h}$ of starvation for phosphorus, which corresponds to the time of development of prolonged culturability at $5{ }^{\circ} \mathrm{C}$ by cells starved under these conditions.

The patterns of protein expression under the different starvation conditions were compared with that during exponential growth in $2 \mathrm{M}$ medium (Fig. 4a) by visual inspection of the autoradiograms. Induced proteins were given a number designation as summarized in Table 2. Autoradiograms of representative gels are shown in Fig. 4 , and an analysis of the proteins induced by the different conditions is depicted in Fig. 5.

After $1 \mathrm{~h}$ starvation, the repression of many proteins was observed and, for each individual starvation condition examined, a specific group of proteins was induced compared to those expressed during exponential growth. Each response consisted of a unique set of induced proteins and subsets common to other conditions. The greatest overlap was observed between the carbon and multiple starvation responses, which appeared to be almost identical. The least overlap was detected between phosphorus starvation and any other starvation condition (Fig. 5). Two of the proteins $(33,34)$ were induced after $1 \mathrm{~h}$ under all four starvation conditions.

Thirty-four proteins (nos 1-34) were induced after $1 \mathrm{~h}$ carbon starvation, and were also induced by multiplenutrient starvation. The only difference in the protein patterns induced by these two starvation conditions was protein no. 35, which was specifically induced during multiple-nutrient starvation (Fig. 4b). Twenty-five (nos 1-25) of the induced proteins were unique for carbon and multiple-nutrient starvation, and seven (nos 26-32) were common to proteins induced during carbon and nitrogen starvation in addition to the above-mentioned proteins which were induced by $1 \mathrm{~h}$ under all four starvation conditions (nos 33 and 34).

When the protein pattern displayed by cells after $1 \mathrm{~h}$ nitrogen starvation was compared to that of an exponentially-growing culture, 24 induced proteins could be detected (Fig. 4c). Of these, 14 proteins (nos 36-49) were unique for nitrogen starvation, while the remaining proteins were also induced by other conditions. In addition to the seven proteins induced during both nitrogen and carbon starvation and the two general starvation proteins (see above), one protein (no. 50) was common to nitrogen and phosphorus starvation.

Ten proteins were induced after $1 \mathrm{~h}$ phosphorus starvation. Of these, seven (nos 51-57) were uniquely induced by phosphorus starvation, and three (nos 33, 34 and 50) were also part of other responses, as described above. After $18 \mathrm{~h}$ phosphorus starvation (Fig. 4d), the phosphorus-starvation proteins nos 51-57 were still induced, but the other proteins (nos 33, 34 and 50) were repressed. Instead, several of the proteins belonging to the nitrogen-starvation set (nos 41, 42, 45 and 48) and, in addition, protein no. 27 (also induced after $1 \mathrm{~h}$ carbon, nitrogen or multiple starvation), were induced by $18 \mathrm{~h}$ phosphorus starvation. An additional set of $30-35$ proteins was detected to be induced at this time; these proteins were not induced after $1 \mathrm{~h}$ starvation for either phosphorus, nitrogen or carbon, and are thus part of the 'late' response of phosphorus-starved cells. After 21 and $24 \mathrm{~h}$ phosphate starvation (data not shown), the protein patterns were very similar to those obtained at $18 \mathrm{~h}$; no new proteins could be observed to be induced in addition to those detected at $18 \mathrm{~h}$, and most proteins remained induced at very similar levels during the subsequent hours of starvation. Some proteins, such as nos 53 and 57 and several of the 'late' group of phosphorus starvation proteins, however, were repressed at $24 \mathrm{~h}$ starvation for phosphorus (data not shown), indicating that a major part of the response to phosphorus starvation was concluded by this time.

\section{DISCUSSION}

Starvation has been shown to induce a multitude of responses in bacteria depending on the nutrient causing growth arrest, as summarized in several recent reviews (Harder \& Dijkhuizen, 1983; Mason \& Egli, 1993; Wanner \& Egli, 1990). In this study, we have investigated the effect of starvation for individual nutrients on the maintenance of culturability of $V$. vulnificus during cold incubation, and examined the initial phases of starvation by two-dimensional gel electrophoresis of pulse-labelled proteins.

\section{Starvation survival at $24^{\circ} \mathrm{C}$}

In $V$. vulnificus, starvation for carbon, nitrogen or phosphorus, or for all three nutrients simultaneously, led to similar survival patterns, as assayed by culturable counts, when the cells were held at $24^{\circ} \mathrm{C}$ (Table 1). In Vibrio sp. S14, the most thoroughly studied marine bacterium, starvation for carbon and multiple nutrients leads to the formation of ultramicrocells with maintained culturability, whereas starvation for phosphorus or nitrogen induces abnormal cell morphology, delays recovery and causes loss of culturability (Holmquist \& 


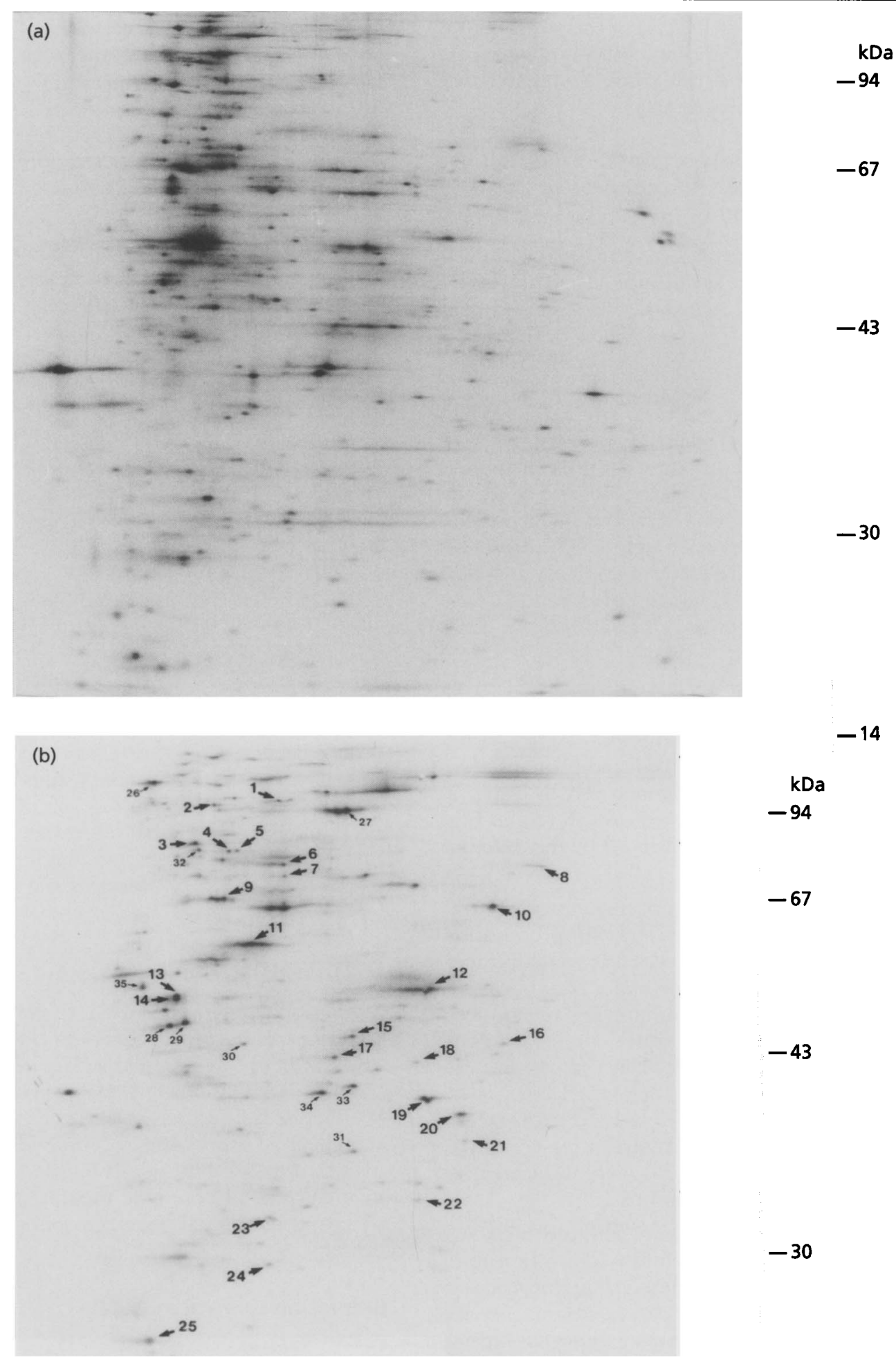

Fig. 4. For legend see facing page.

Kjelleberg, 1993). Pseudomonas putida KT2442 maintains near complete culturability during carbon and multiplenutrient starvation, and responds similarly during nitrogen starvation, but appears to be sensitive to phosphate starvation (Givskov et al., 1994b).
The morphology of cells of $V$. vulnificus starved of carbon, phosphorus, nitrogen, or multiple nutrients is very similar to that described for cells of Vibrio sp. S14 starved for the same nutrient(s) (Holmquist \& Kjelleberg, 1993) : carbonstarved and multiple-nutrient starved cells are small 


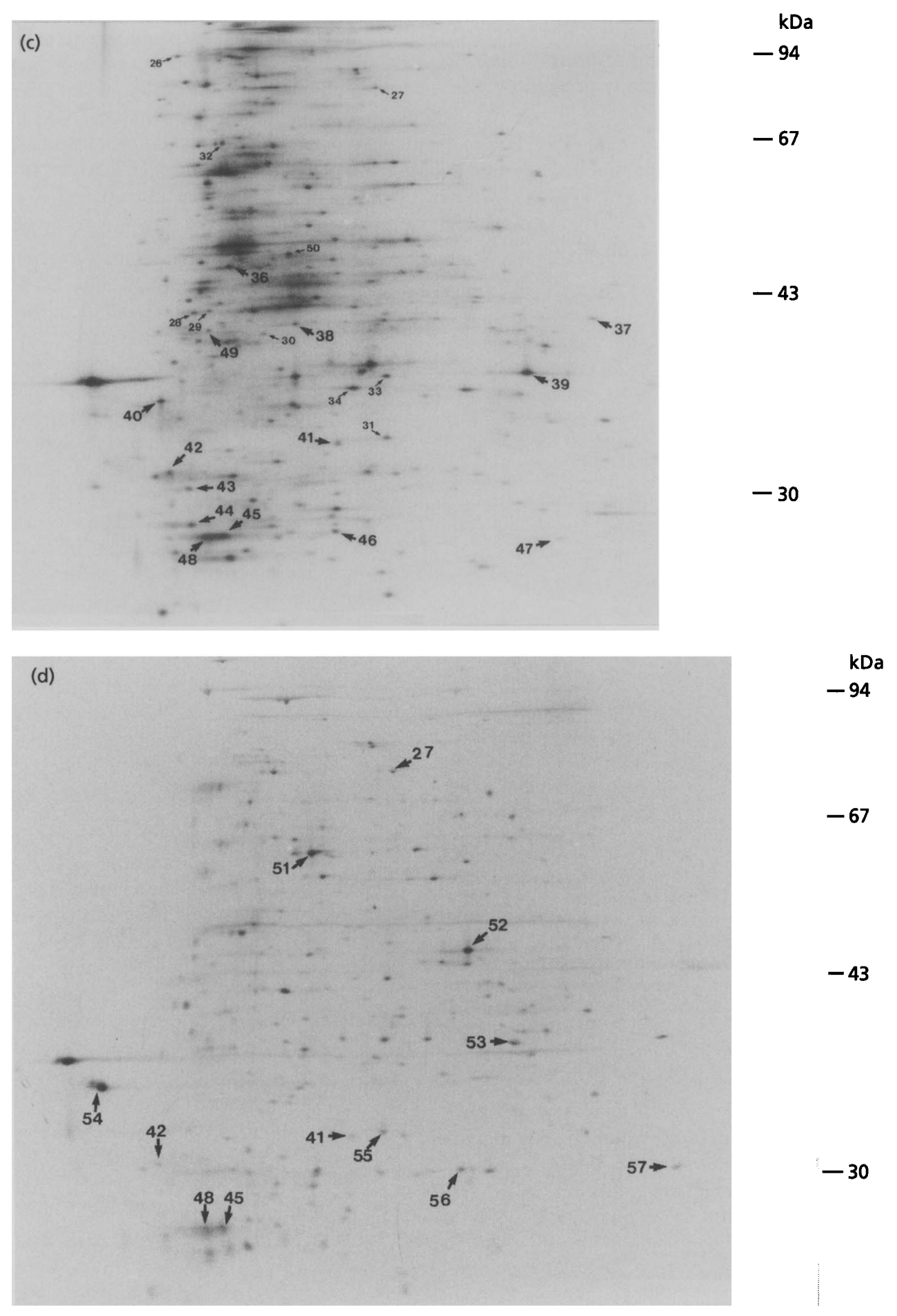

Fig. 4. Autoradiograms of two-dimensional protein gels of $V$. vulnificus labelled with $\left[{ }^{35} S\right]$ methionine during exponential growth at $24^{\circ} \mathrm{C}$ in $2 \mathrm{M}$ medium (a), after $1 \mathrm{~h}$ starvation for carbon, nitrogen and phosphorus (CNP, multiple starvation; b), after $1 \mathrm{~h}$ starvation for nitrogen (c) and after $18 \mathrm{~h}$ starvation for phosphorus (d). The pattern induced by starvation for carbon was almost identical to that pattern induced by multiple starvation (b, with the exception of protein no. 35 , see Table 2 and text), and is thus not shown. The proteins induced after $1 \mathrm{~h}$ phosphorus starvation are all part of the pattern obtained after $18 \mathrm{~h}$ phosphorus starvation (see Table 2 and text); an autoradiogram with the protein pattern induced after $1 \mathrm{~h}$ is thus not shown. The gels depicted are representative of duplicates; induced proteins are indicated by arrows numbered according to Table 2 . The left side of the photographs corresponds to the acidic end of the isoelectric focusing gels. On the right margin, the positions of protein molecular mass standards on the gels are indicated. 
Table 2. Numbering and grouping of induced proteins after $1 \mathrm{~h}$ starvation at $24^{\circ} \mathrm{C}$ for carbon (C), nitrogen (N), phosphorus $(P)$ or all three nutrients simultaneously (multiple) compared to an exponentially growing culture

\begin{tabular}{|c|c|}
\hline Starvation for & Proteins induced \\
\hline $\mathrm{C}$ and multiple & $\begin{array}{l}1,2,3,4,5,6,7,8,9,10,11,12,13 \\
14,15,16,17,18,19,20,21,22 \\
23,24,25\end{array}$ \\
\hline $\mathrm{C}, \mathrm{N}$ and multiple & $26,27,28,29,30,31,32$ \\
\hline $\mathrm{C}, \mathrm{N}, \mathrm{P}$ and multiple & 33,34 \\
\hline Multiple & 35 \\
\hline $\mathrm{N}$ & $\begin{array}{l}36,37,38,39,40,41,42,43,44,45 \\
46,47,48,49\end{array}$ \\
\hline $\mathrm{N}$ and $\mathrm{P}$ & 50 \\
\hline $\mathrm{P}$ & $51,52,53,54,55,56,57$ \\
\hline
\end{tabular}

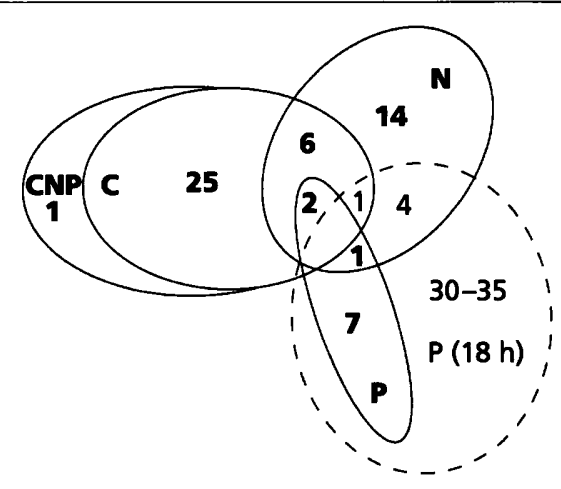

Fig. 5. Venn diagram of the numbers of proteins induced after $1 \mathrm{~h}$ starvation (solid circles, bold type) for carbon (C), nitrogen (N), phosphorus (P) or all three nutrients simultaneously (CNP) compared to an exponentially growing culture. Proteins induced after $18 \mathrm{~h}$ starvation for phosphorus are contained within the dashed circle (normal typescript). The analysis is based on the autoradiograms shown in Fig. 4, and has been verified by comparison with the gels of samples from independent experiments.

coccoid cells or short rods; phosphorus-starved cells display swollen filaments with several inclusion bodies which may represent PHB depositions; nitrogen-starved cells have very irregular morphology ranging from long filaments to swollen or coccoid cells (data not shown).

\section{Effects of extracellular factors}

Recently, a large number of reports have implicated extracellular products of bacteria in the regulation of a wide variety of microbial processes, and sensing of cell density and signalling by pheromone-like substances. Derivatives of acylated homoserine lactone have been observed in various bacterial species including $V$. fischeri and $V$. harveyi (Kaiser \& Losick, 1993; Kell et al., 1995). Further, homoserine lactone has been proposed as a starvation signal in E. coli (Huisman \& Kolter, 1994). It is thus possible that the prolonged culturability observed for pre-starved $V$. vulnificus subsequently incubated at $5^{\circ} \mathrm{C}$ is triggered by extracellular products which signal growth arrest and prepare the cells for stationary-phase survival. The hypothesis that factors excreted by $V$. vulnificus, $V$. fischeri or $V$. harveyi affect the transition to the VBNC state in $V$. vulnificus was tested by addition of supernatants of starved or stationary-phase cultures of $V$. vulnificus, $V$. fischeri or $V$. barveyi. None of these additions altered the culturability of $V$. vulnificus during cold incubation.

We have previously shown (Weichart et al., 1992) that the induction of the VBNC state of $V$. vulnificus is at least partly triggered by products released by cold-incubated cells. To test the possibility that the maintenance of prolonged culturability during cold exposure afforded by starvation is due to the induction of extracellular proteases (Kreger \& Lockwood, 1981), which could serve to remove the 'killing factor(s)' secreted by cold incubated cells, we tested the effect of the non-specific protease inhibitor $\alpha$-2-macroglobulin (Miyoshi \& Shinoda, 1991; Sottrop-Jensen, 1989) on starving cells. The inhibitor was shown to be fully functional in our experimental system, but it had no effect on the culturability of pre-starved cells during cold incubation.

The experiments involving supernatants and protease inhibitor suggest that the effect of starvation on the culturability of $V$. vulnificus during cold incubation is not triggered or affected by extracellular substances secreted by the organism during starvation.

\section{Effects of starvation conditions on culturability at $5^{\circ} \mathrm{C}$}

In earlier reports, multiple-nutrient starvation prior to cold incubation has been shown to prolong the culturability of $V$. vulnificus at $5{ }^{\circ} \mathrm{C}$, and thus delay the formation of VBNC cells (Oliver et al., 1991; Weichart et al., 1992). The specificity of the development of prolonged culturability during starvation in relation to the nutrient which is limiting growth has not previously been investigated in $V$. vulnificus. In this paper, we have addressed this issue with regard to the response of the organism to cold incubation. Carbon and multiple-nutrient starvation were almost indistinguishable in their effect on culturability of $V$. vulnificus during cold exposure (Fig. 1). Both gave rise to a significant effect on culturability after $1 \mathrm{~h}$ starvation at $24^{\circ} \mathrm{C}$, and a pronounced effect after $24 \mathrm{~h}$.

Notably, phosphorus starvation was almost as efficient in prolonging culturability of $V$. vulnificus cells during cold exposure as carbon and multiple starvation, although the response to phosphorus starvation appeared to be delayed (Figs 2 and 3 ). Phosphorus starvation at $24^{\circ} \mathrm{C}$ for up to $15 \mathrm{~h}$ does not lead to detectable increases in maintenance of culturability at low temperature (Fig. 3). This could be due to transient continuation of growth in the absence of external sources of phosphorus by utilization of phosphorus-containing membrane constituents as has been observed in a marine Pseudomonas fuorescens (Minnikin \& Abdolrahimzadeh, 1974).

Starvation for nitrogen, however, did not promote prolonged culturability in $V$. vulnificus during incubation 
at low temperature, even when the pre-starvation times were extended to $72 \mathrm{~h}$ (Fig. 2). From this we can conclude that the induction of general post-exponential (Pex) proteins does not permit prolonged maintenance of culturability during cold exposure in $V$. vulnificus. These Pex proteins have been reported to provide the basis of starvation-induced cross protection in E. coli (Jenkins $e t$ al., 1988) and possibly also Pseudomonas putida (Kim et al., 1995). It is not known why nitrogen starvation does not allow maintenance of culturability in $V$. vulnificus, while the survival of the organism in the absence of an external source of nitrogen is not impaired at $24^{\circ} \mathrm{C}$ (Table 1). It is possible that the failure to maintain culturability at low temperature after nitrogen starvation could be due to the inability of the organism to balance amino acid or protein pools in order to prepare the cells for the shutdown of protein synthesis caused by cold stress. The synthesis and turnover of proteins are reported to be unaffected or even increased in nitrogen-limited E. coli due to breakdown of ribosomes (Mandelstam \& Halvorson, 1960).

\section{Analysis of protein synthesis during starvation}

In order to elucidate the molecular determinants for maintenance of culturability, we have commenced the analysis of the proteins induced during the initial phases of starvation for the different nutrients. In this study, a set of more than 34 proteins were identified which were induced during $1 \mathrm{~h}$ of carbon- or multiple-nutrient starvation and which might be involved in the maintenance of culturability during cold incubation. As prestarvation for phosphorus for $18 \mathrm{~h}$ allowed for prolonged culturability analogous to that afforded by $1 \mathrm{~h}$ carbon starvation, the proteins induced after $18 \mathrm{~h}$ were included in the analysis. Starvation for phosphorus induced a response which was clearly different from that to carbon or multiple-nutrient starvation: 10 proteins were induced after $1 \mathrm{~h}$, and additionally 30-35 proteins were induced after $18 \mathrm{~h}$ of phosphorus starvation. In the protein patterns, as visualized by two-dimensional gel electrophoresis, the overlap between the three responses (C, P and multiple starvation) only comprised proteins which were also induced by nitrogen starvation; after $1 \mathrm{~h}$ two proteins and after $18 \mathrm{~h}$ one protein (nos 33,34 and 27 respectively; Table 2, Fig. 5). As nitrogen starvation itself did not allow for prolonged culturability at $5{ }^{\circ} \mathrm{C}$, it may be concluded that these proteins do not mediate maintenance of culturability of cold-incubated cells. It is postulated that the proteins induced by carbon and phosphorus starvation are part of independent responses which allow for maintenance of culturability at low temperature.

Recently the pattern of carbon-starvation-induced proteins was examined in the opaque variant of $V$. vulnificus (Morton \& Oliver, 1994). However, the data presented by Morton \& Oliver (1994) reflect a mixture of responses, namely the stringent response, as the amino acids present in the growth medium are withdrawn at the onset of starvation, and a diauxic shift, as the utilizable carbon source acetate remains in the 'starvation medium'. Hence the protein patterns published by Morton \& Oliver (1994) are not comparable or related to the patterns reported here.

Induction patterns similar to those described here have been reported in other bacteria: in E. coli (Jenkins et al., 1988; Matin, 1991), Salmonella typhimurium (Spector et al., 1986), Pseudomonas putida (Givskov et al., 1994a) and Vibrio sp. S14 (Nyström et al., 1992) sets of unique responses to the individual starvation conditions, as well as overlapping responses, were found. In all cases, a fraction of the protein responders is induced regardless of the starvation condition encountered, and the individual starvation conditions share particular subgroups of induction. It appears as if specific regulators and general regulatory mechanisms interact on many levels in the coordination and modulation of starvation responses. This phenomenon of multi-level regulation may be concluded to exist in several organisms including Vibrio species.

The proteins induced by carbon starvation in V. vulnificus include nearly all the proteins induced by multiple starvation, whereas the patterns induced by other conditions overlap only to a minor extent with the response induced by multiple starvation (Fig. 5). This indicates that carbon starvation determines or dominates the response to multiple starvation in $V$. vulnificus. In Vibrio sp. S14, the protein pattern characteristic for multiple starvation does not show any greater resemblance to that characteristic for carbon starvation than it does to those patterns typical for other starvation conditions (Nyström et al., 1992). Also, in Vibrio sp. S14 a large group of proteins is induced by multiple starvation only, and not by the individual starvation conditions, while we have detected only one such protein in the initial phase of starvation in $V$. vulnificus. The results obtained for starvation survival, maintenance of prolonged culturability at low temperature and starvation-induced protein synthesis indicate that the starvation responses in $V$. vulnificus are different from those in Vibrio sp. S14. This is further supported by the previously reported observation that the induction of stress proteins by carbon starvation is dissimilar in the two Vibrio species (Holmquist et al., 1992).

The results reported here constitute the first step in determining the cellular mechanism behind the interaction between starvation and the cold-induced loss of culturability of cells of $V$. vulnificus. We have identified carbon (or multiple-nutrient) starvation and phosphorus starvation as conditions that induce maintenance of culturability during cold exposure. The analysis of the patterns of induced proteins has allowed us to conclude that carbon starvation determines the response of the organism to multiple-nutrient starvation, and that carbon and phosphorus starvation may elicit maintenance of culturability via induction of different proteins, indicating the possibility of different specific molecular responses. We propose that the characterization at a molecular level of the processes leading to the loss of culturability, as well as those responsible for the initiation of resuscitation, will provide us with a better understanding of the ecology and epidemiology of the pathogen $V$. vulnificus and facilitate the development of possible control measures. 


\section{ACKNOWLEDGEMENTS}

This work was supported by grants from the Swedish National Environmental Protection Agency (EC-BIO'TECHNOLOGY Program) and the Australian Research Council. Christine Paludan-Müller was supported by a Danish State Education grant and an Education International grant. We thank Dr Lone Gram and Dr Michael Givskov, Technical University of Denmark, for helpful discussions and comments on the manuscript.

\section{REFERENCES}

Colwell, R. R., Brayton, P. R., Grimes, D. J., Roszak, D. B., Huq, S. A. \& Palmer, L. M. (1985). Viable but nonculturable Vibrio cholerae and related pathogens in the environment: implications for release of genetically engineered microorganisms. Bio/Technology 3 , 817-820.

Givskov, M., Eberl, L. \& Molin, S. (1994a). Responses to nutrient starvation in Pseudomonas putida KT2442: two-dimensional electrophoretic analysis of starvation- and stress-induced proteins. $J$ Bacteriol 176, 4816-4824.

Givskov, M., Eberl, L., Møller, S., Kongsbak Poulsen, L. \& Molin, S. (1994b). Responses to nutrient starvation in Pseudomonas putida KT2442: analysis of general cross-protection, cell shape, and macromolecular content. J Bacteriol 176, 7-14.

Harder, W. \& Dijkhuizen, L. (1983). Physiological responses to nutrient limitation. Annu Rev Microbiol 37, 1-23.

Hoben, H. J. \& Somasegaran, P. (1982). Comparison of the pour, spread and drop plate methods for enumeration of Rbizobium spp. in inoculants made from presterilized peat. Appl Environ Microbiol 44, 1246-1247.

Holmquist, L. \& Kjelleberg, S. (1993). Changes in viability, respiratory activity and morphology of the marine Vibrio sp. strain S14 during starvation of individual nutrients and subsequent recovery. FEMS Microbiol Ecol 12, 215-224.

Holmquist, L., Jouper-Jaan, Å., Weichart, D., Nelson, D. R. \& Kjelleberg, S. (1992). The induction of stress proteins in three marine Vibrio during carbon starvation. FEMS Microbiol Ecol 12, 185-194.

Huisman, G. W. \& Kolter, R. (1994). Sensing starvation: a homoserine lactone-dependent signalling pathway in Escherichia coli. Science 265, 537-539.

Jenkins, D. E., Schultz, J. E. \& Matin, A. (1988). Starvation-induced cross protection against heat or $\mathrm{H}_{2} \mathrm{O}_{2}$ challenge in Escherichia coli. $J$ Bacteriol 170, 3910-3914.

Kaiser, D. \& Losick, R. (1993). How and why bacteria talk to each other. Cell 73, 873-885.

Kell, D. B., Kaprelyants, A. S. \& Grafen, A. (1995). Pheromones, social behaviour and the functions of secondary metabolism in bacteria. Trends Ecol Evol 10, 126-129.

Kim, Y., Watrud, L. S. \& Matin, A. (1995). A carbon starvation survival gene of Pseudomonas putida is regulated by $\sigma^{54}$. J Bacteriol 177, 1850-1859.

Kreger, A. \& Lockwood, D. (1981). Detection of extracellular toxin(s) produced by Vibrio vulnificus. Infect Immun 33, 583-590.

Mandelstam, J. \& Halvorson, H. (1960). Turnover of protein and nucleic acid in soluble and ribosome fractions of non-growing Escherichia coli. Biochim Biophys Acta 40, 43-49.

Mason, C. A. \& Egli, T. (1993). Dynamics of microbial growth in the decelerating and stationary phase of batch culture. In Starvation in
Bacteria, pp. 81-102. Edited by S. Kjelleberg. New York \& London: Plenum Press.

Matin, A. (1991). The molecular basis of carbon-starvation-induced general resistance in Escherichia coli. Mol Microbiol 5, 3-10.

Minnikin, D. E. \& Abdolrahimzadeh, H. (1974). The replacement of phosphatidylethanolamine and acidic phospholipids by an ornithine-amine lipid and a minor phosphorus-free lipid in Pseudomonas fuorescens NCMB 129. FEBS Lett 43, 257-259.

Miyoshi, S. \& Shinoda, S. (1991). $\alpha$-Macroglobulin-like plasma inactivator for Vibrio vulnificus metalloprotease. $J$ Biochem 110, 548-552.

Morton, D. S. \& Oliver, J. D. (1994). Induction of carbon starvationinduced proteins in Vibrio vulnificus. Appl Environ Microbiol 60, 3653-3659.

Morton, D. S., El-Janne, M. \& Oliver, J. D. (1992). Macromolecular synthesis in Vibrio vulnificus during starvation and entry into the viable but nonculturable state. Abstr Annu Meet Am Soc Microbiol

Neidhardt, F., Bloch, P. L. \& Smith, D. F. (1974). Culture medium for Enterobacteriaceae. J Bacteriol 119, 736-747.

Nystrőm, T., Mården, P. \& Kjelleberg, S. (1986). Relative changes in incorporation rates of leucine and methionine during starvation survival of two bacteria isolated from marine waters. FEMS Microbiol Ecol 38, 285-292.

Nystrom, T., Olsson, R. M. \& Kjelleberg, S. (1992). Survival, stress resistance and alterations in protein expression in the marine Vibrio sp. strain S14 during starvation for different individual nutrients. Appl Environ Microbiol 58, 55-65.

O'Farrell, P. H. (1975). High-resolution two-dimensional electrophoresis of proteins. J Biol Chem 250, 4007-4021.

Oliver, J. D. (1993). Formation of viable but nonculturable cells. In Starvation in Bacteria, pp. 239-272. Edited by S. Kjelleberg. New York \& London: Plenum Press.

Oliver, J. D., Nilsson, L. \& Kjelleberg, S. (1991). Formation of nonculturable cells of Vibrio vulnificus and its relationship to the starvation state. Appl Environ Microbiol 57, 2640-2644.

Östling, J., Goodman, A. \& Kjelleberg, S. (1991). Behaviour of IncP-1 plasmids and a miniMu transposon in a marine Vibrio sp.: isolation of starvation inducible lac operon fusions. FEMS Microbiol Ecol 86, 83-94.

Simpson, L. M., White, V. K., Zane, S. F. \& Oliver, J. D. (1987). Correlation between virulence and colony morphology in Vibrio vulnificus. Infect Immun 55, 269-272.

Sottrop-Jensen, L. (1989). $\alpha$-Macroglobulins: structure, shape and mechanism of proteinase complex formation. J Biol Chem 264, 11539-11542.

Spector, M. P., Aliabadi, Z., Gonzalez, T. \& Foster, J. W. (1986). Global control in Salmonella typhimurium: two-dimensional electrophoretic analysis of starvation-, anaerobiosis- and heat shockinducible proteins. $J$ Bacteriol 168, 420-424.

Wanner, U. \& Egli, T. (1990). Dynamics of microbial growth and cell composition in batch culture. FEMS Microbiol Rev 75, 19-44.

Weichart, D., Oliver, J. D. \& Kjelleberg, S. (1992). Low temperature induced non-culturability and killing of Vibrio vulnificus. FEMS Microbiol Lett 100, 205-210.

Wolf, P. W. \& Oliver, J. D. (1992). Temperature effects on the viable but nonculturable state of Vibrio vulnificus. FEMS Microbiol Ecol 101, 33-39.

Received 22 December 1995; revised 20 February 1996; accepted 23 February 1996. 